\section{Risk analysis of roof fall and prediction
of damaged regions at retreat longwall \\ Risk analysis of roof fall and prediction
of damaged regions at retreat longwall coal mining face}

Rudarsko-geološko-naftni zbornik

(The Mining-Geology-Petroleum Engineering Bulletin) UDC: 622.2

DOI: 10.17794/rgn.2020.3.9

Original scientific paper

\author{
Sajjad Aghababaei ${ }^{1}$; Gholamreza Saeedi ${ }^{2}$; Hossein Jalalifar ${ }^{3}$ \\ ${ }^{1}$ Shahid Bahonar University of Kerman, Department of Mining Engineering, Kerman, Iran, https://orcid.org/0000-0002-2981-8987 \\ ${ }^{2}$ Shahid Bahonar University of Kerman, Department of Mining Engineering, Kerman, Iran, https://orcid.org/0000-0003-3161-3603 \\ ${ }^{3}$ Shahid Bahonar University of Kerman, Mining and Petroleum Engineering Department, Kerman, Iran, https://orcid.org/0000-0003-4610-5169
}

\begin{abstract}
This study presents a model based on rock engineering systems (RES) to evaluate the risk of roof falls and determine damaged regions, using recorded roof falls, prior to mining with a retreat from a longwall face. In this regard, a case study was considered to examine the model. The results showed that the level of determined risk has an acceptable correlation with the special roof fall (SRF), with R-squared value $\left(\mathrm{R}^{2}\right)$ equal to 0.792 for all estimated vulnerability indexes (VIs) in considered longwall panels. By investigating and comparing the evaluated values of VI in considered panels and their corresponding recorded roof falls, damaged regions were distinguished from undamaged regions. Based on these investigations, four classes including safe, moderate, danger, and critical regions were determined to identify the safe and damaged regions prior to the mining operation. The results of the research showed that the identification of damaged regions is feasible to provide a detailed operation plan to control roof falls in longwall mining faces through the developed approach. The RES-based model could be used for the same conditions and the presented methodology could be applied to other parts in underground coal mines.
\end{abstract}

\title{
Keywords:
}

Roof fall; Rock engineering systems; Damaged regions; Longwall method; Coal mining

\section{Introduction}

Coal mining by the underground method has been always one of the most dangerous mining methods, with the highest rate of injuries, fatalities, and damages. Working faces in underground coal mines, especially longwall faces, requires continuous advancing and the avoidance of stoppages since interruptions in progress could cause roof falls. Roof falls are the most critical cause of damages in underground coal mines. So, presentation and development of a method to identify and control roof falls is always a priority. A roof fall at a longwall face is defined in three dimensions as shown in Figure 1. The third dimension is the length of a fall that is specified along the face line.

Recently, extensive studies have been carried out to assess risks and control the roof falls in underground coal mines. In this paper, some of these studies are mentioned. Molinda et al. (2000) stated that the coal mine roof rating (CMRR) is the foremost indicator to predict the roof fall rate. They divided the areas into the ranges of safe to dangerous by evaluating the relationship between the recorded falls and CMRR. Deb (2003) applied

Corresponding author: Gholamreza Saeedi gsaeedi@uk.ac.ir an approach to analyse the roof fall rate using fuzzy reasoning techniques in coal mines. The presented outline involved three variables consisting of the intersection diagonal span (IDS), the primary roof support (PRSUP), and CMRR. Duzgun and Einstein (2004) presented a risk and decision analysis methodology to assess and manage the risk of roof falls. In this study, the time intervals between the roof fall accidents and the number of roof falls each year were considered for the probability assessments (objective method). Decision analysis has involved two actions, consisting of "do nothing" and "support improvement". Maiti and Khanzode (2009) developed a relative risk model for roof and side fall fatalities by three safety performance indicators including potential fatalities, relative risk of fatalities and safety measure effectiveness. Palei and Das (2009) conducted a logistic regression model to predict the roof fall risks in board and pillar workings in coal mines and also investigated the relationship between the major contributing parameters and accidents. They considered seven variables consisting of geological, design and operational factors for their model. Ghasemi et al. (2012) provided a method for the evaluation of roof fall risk using semi-quantity techniques. In this regard, they identified the effective parameters and then explained the role of each parameter on roof falls. In this research, eighteen 


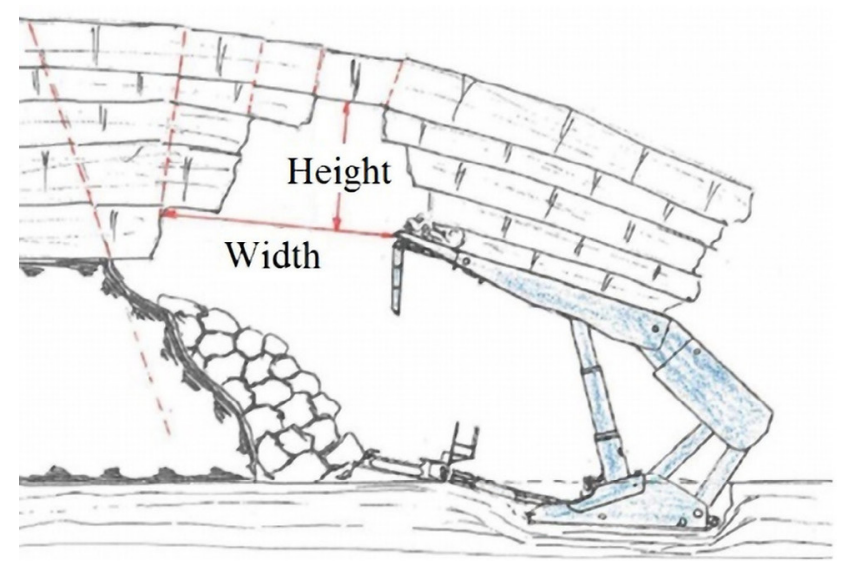

Figure 1: A roof fall at a longwall face, after (Prusek et al., 2017)

geological, design and operational parameters were considered for the presented model. Razania et al. (2013) used a fuzzy inference system to predict the rate of roof falls. CMRR, depth of cover, mining height, intersection diagonals and PRSUP were considered as effective parameters. They investigated the performance of the presented approach by comparison of actual and predicted roof fall rates. Prusek et al. (2017) determined the major factors influencing the stability of a roof in retreat from a longwall panel and then provided a practical method for assessing the risk of roof fall based on these factors. In this study, an investigator used to determine the probability and potential consequences of roof falls. Canbulat et al. (2017) assessed risks of sinkhole occurrences associated with shallow board and pillar mining. Zhang et al. (2018) conducted a numerical modelling study to investigate the effect of the longwall retreat direction on stress concentrations in the headgate and then discussed the causes and risks of roof falls in the longwall belt entry, and mitigation measures for roof-fall risks. Luo et al. (2019) presented a model to evaluate the risk of ground control collapse in goaf based on unascertained measures. Yong et al. (2019) proposed an object-oriented model base framework that realizes model management and a model reused to evaluate the geological hazards in mines effectively and systematically. Zilong et al. (2019) presented a new risk assessment model incorporating the stability of individual pillars and the load transfer between pillars was proposed to investigate the cascading failure of pillar sections.

RES have been widely applied in the field of mining and civil engineering. In the field of underground mining, these studies are listed including the assessment of rock mass cavability in block caving mines (Rafiee et al. 2015), development of a destressability index methodology for the assessment of the likelihood of success of a large-scale confined destress blast in an underground mine pillar (Andrieux and Hadjigeorgiou 2008), evaluation and classification of coal spontaneous combustion potential in coal mines (Saffari et al. 2013), predicting the level of risk due to out-of-seam dilution (OSD) in longwall faces (Bahri et al. 2014), analysing and predicting the floor failure mechanisms at longwall face (Aghababaei et al. 2015), quantifying rock mass behavior underground (Adoko et al. 2016), geohazard risk assessment in coal mines (Vaziri et al. 2017), evaluating the comprehensive outburst index in coal mines (Zhou et al. 2017), determination and assessment of coal bed methane potential in coal mines (Ghanbari et al. 2018), the application of a system of thinking-based techniques for the assessment of rock mass cavability in block caving mines (Rafiee et al. 2018), predicting the face advance rate and determining the operation efficiency in retreat longwall mining (Aghababaei et al. 2019), introducing a coal seam methane drainageability index (CMDI) for predrainage techniques in a working mine (Najafi and Rafiee 2019), and presenting an index entitled rock burst damage scale (RDSI) to predict the scale of damage due to rock burst hazards (Ning et al 2019).

This research provides an approach to identify the damaged regions, refers to regions where the roof falls happen, in retreat from longwall mining panels with the aim of planning crisis management prior to mining. For this purpose, a model based on RES is proposed to evaluate the risk of roof falls and identifying the damaged regions, using recorded roof falls. Performance evaluation of the model requires a suitable case study. So, a case study is considered and the presented model is examined.

\section{Case Study}

The case study consists of six longwall panels including $\mathrm{E}_{0}, \mathrm{E}_{2}, \mathrm{E}_{3}, \mathrm{~W}_{0}, \mathrm{~W}_{1}$ and $\mathrm{W}_{2}$ in Parvadeh-I coal mine (see Figure 2). The $\mathrm{E}_{1}$ panel is not included due to lack of data. Roof falls at the Parvadeh-I coal mine cause a lot of damages. Some of these falls were so large that they caused a reduction of the face advance rate to $0.1 \mathrm{~m}$ /day several times and a lot of damages to the extraction equipment. In this mine, floor failure is other instability in the longwall face which is in close interaction with roof fall.

Parvadeh-I is in the south-east of Tabas, Iran. In this mine (IRASCO et al., 2005a; IRASCO et al., 2005b), the extracting coal seam is inclined 22 degrees with a thickness of $2 \mathrm{~m}$ and the main surrounding geological units are mudstone, siltstone and sandstone. The direction of larger horizontal stress is from north east to south west. Also, Table 1 provides a summary of information about the considered panels. The powered supports are controlled by a manual control system in Parvadeh-I.

\section{Method}

\subsection{A brief summary of rock engineering systems}

Hudson (1992) presented an approach named rock engineering system (RES) to analyse the interaction between the effective parameters and components involved in rock mass for evaluating and answering complex en- 


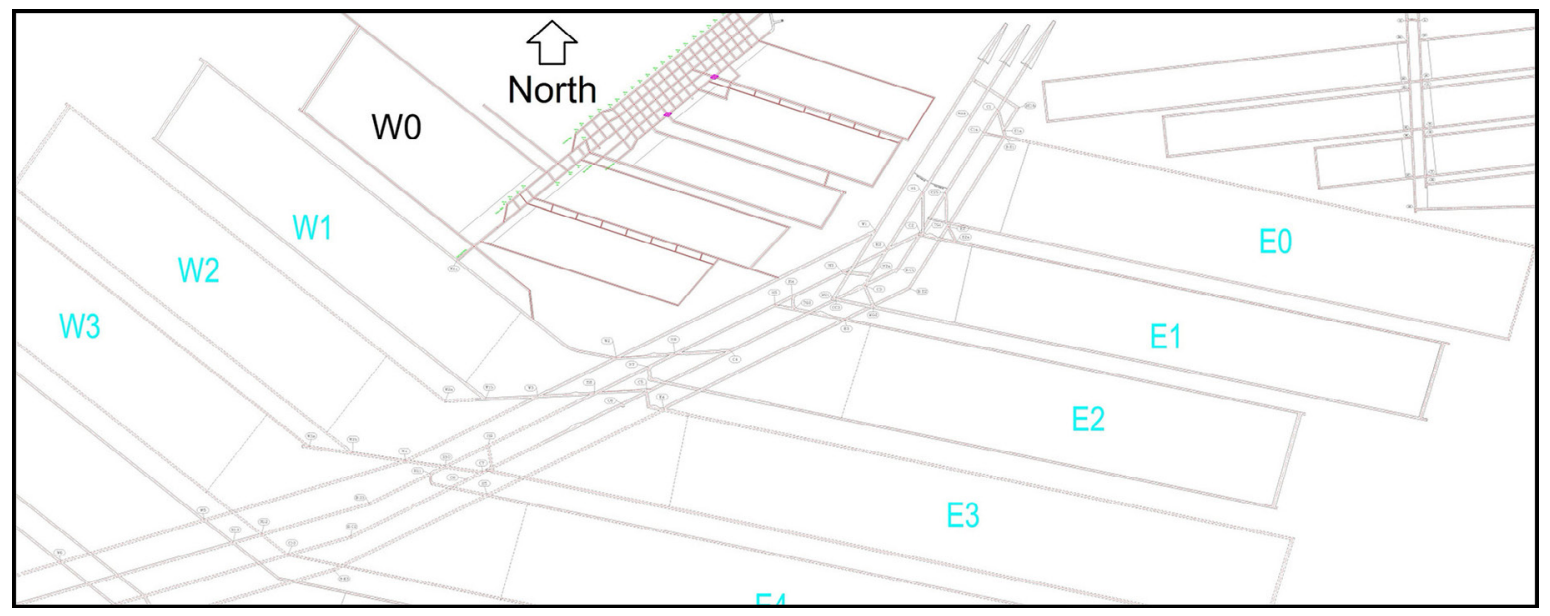

Figure 2: Considered longwall panels in Parvadeh-I

Table 1: A brief information of considered longwall panels

\begin{tabular}{|l|l|l|l|l|}
\hline $\begin{array}{l}\text { Panel } \\
\text { code }\end{array}$ & $\begin{array}{l}\text { Depth } \\
(\mathbf{m})\end{array}$ & $\begin{array}{l}\text { Panel width } \\
(\mathbf{m})\end{array}$ & $\begin{array}{l}\text { Average dip of coal } \\
\text { seam (degree) }\end{array}$ & Description \\
\hline $\mathrm{W}_{0}$ & 180 & 207 & $<15$ & Extracted, Roof falls with height 0.3 to $0.9 \mathrm{~m}$ are not recorded \\
\hline $\mathrm{W}_{1}$ & 260 & 190.5 & 15.7 & Extracted, Roof falls with height 0.3 to $0.9 \mathrm{~m}$ are not recorded \\
\hline $\mathrm{W}_{2}$ & 365 & 205.5 & 12.8 & Extracted, Roof falls with height 0.3 to $0.9 \mathrm{~m}$ are not recorded \\
\hline $\mathrm{E}_{0}$ & 95 & 198 & 12.4 & Extracted, Roof falls with height 0.3 to $0.9 \mathrm{~m}$ are not recorded \\
\hline $\mathrm{E}_{2}$ & 250 & 213 & 24.9 & Extracted \\
\hline $\mathrm{E}_{3}$ & 368 & 207 & 19 & $\begin{array}{l}\text { Is extracting in Sep. 2018, Roof falls with height } 0.3 \text { to } 0.9 \mathrm{~m} \text { are not } \\
\text { recorded }\end{array}$ \\
\hline
\end{tabular}

gineering issues. The RES determines and quantifies the interaction between parameters involved in a system. This process can be done by an interaction matrix as the key element of RES (see Figure 3). An $n * n$ interaction matrix created by $n$ parameters affecting the system. The off-diagonal positions in the matrix are filled by values describing the degree of interaction between the parameters. This research has adopted the "expert semi-quantitative" (ESQ) method (Hudson, 1992) for numerically coding the interaction matrix, in such a way that 0 is assigned for no interaction, 1 for weak, 2 for medium, 3 for strong, and 4 for critical interaction respectively. According to Figure 3, each particular parameter is denoted as coordinates $(\mathrm{C}, \mathrm{E}), \mathrm{C}$ and $\mathrm{E}$ are cause and effect. The interaction matrix helps in determining the weighting of each effective parameter within the system by Equation 1, where $C_{i}$ and $E_{i}$ are the cause and effect of the $\mathrm{i}^{\text {th }}$ parameter, respectively.

$$
a_{i}=\frac{\left(C_{i}+E_{i}\right)}{\left(\sum_{i=1}^{n} C+\sum_{i=1}^{n} E\right)}
$$

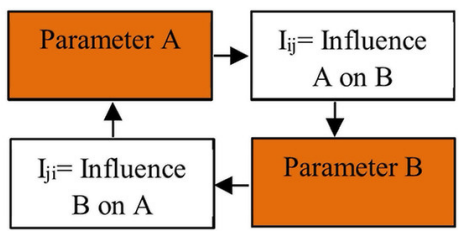

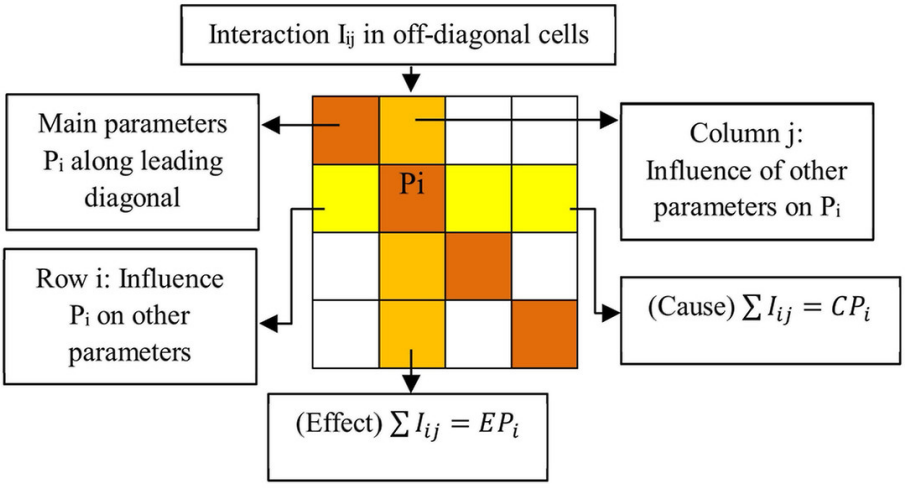

Figure 3: A general view of interaction matrix including principle of interaction between two parameters and matrix coding (taken after (Hudson, 1992)) 


\subsection{Applied approach for the research}

The approach is based on estimating the risk of roof fall in each panel and comparing it with the corresponding roof fall which occurred previously to identify the damaged regions in the extracted panels and use the obtained results to predict the damaging regions in the next longwall panels. Here, Equation 2 presented by Benardos and Kaliampakos (2004) is used to determine the risk of roof falls. Evaluating the capability of the provided RES-based model is carried out by investigating the relationship between the average of estimated roof fall risks and special roof fall (SRF) for the considered panels. A special roof fall in a panel is determined by Equation 3. In Equations 2 and 3, VI is the vulnerability index referring risk of a roof fall, $\mathrm{a}_{\mathrm{i}}$ is the weighting of the $i^{\text {th }}$ parameter (evaluate by RES), $Q_{i}$ is the value (rating) of the $i^{\text {th }}$ parameter, $\mathrm{Q}_{\max }$ is the maximum value assigned for the $i^{\text {th }}$ parameter (normalization factor), TVRF is the total volume of roof falls in the panel $\left(\mathrm{m}^{3}\right)$ and EAP is the extracted area of the panel $\left(\mathrm{m}^{2}\right)$. VIs of 0 and 100 show the lowest and highest risk level, respectively.

$$
\begin{gathered}
V I=100-\sum_{i=1} a_{i} \frac{Q_{i}}{Q_{\max }} \\
S R F=\frac{T V R F}{E A P}
\end{gathered}
$$

Accurate calculation of VI in each panel requires the organization of a database along each panel gate. Therefore, for the considered case study, the length of each gate was divided into intervals with equal distance and required data by all of the recorded and surveyed geological and geomechanical information determined for them. Then, VI for each interval is determined and the results are used to determine the corresponding VI of each recorded roof fall. In the present study, 486 datasets were collected along all the considered panel gates to evaluate the risk of roof falls. In the following analysis, information regarding 321 recorded roof falls (for each roof fall, two corresponding VIs is assigned, one in tailgate and another in maingate of each panel, so total number of corresponding VIs for roof falls are 642) was collected and processed.

\subsection{Presenting the RES-based model}

To generate the reaction matrix, nine main effective parameters on roof falls in a longwall mining face are considered in the RES-based model including CMRR $\left(\mathrm{P}_{1}\right)$, Coal- roof interface strength $\left(\mathrm{P}_{2}\right)$, safety factor of face $\left(\mathrm{P}_{3}\right)$, the ratio of joint spacing to cutting depth at face $\left(\mathrm{P}_{4}\right)$, longitudinal inclination of face $\left(\mathrm{P}_{5}\right)$, panel width $\left(\mathrm{P}_{6}\right)$, rock mass rating (RMR) of floor $\left(\mathrm{P}_{7}\right)$, type of control system of Powered supports $\left(\mathrm{P}_{8}\right)$ and Distance of roof layers overhanging (cantilever) from roof line at face $\left(\mathrm{P}_{9}\right)$. The safety factor of face (SF) be estimated by Equation 4 (Aghababaei et al., 2015), where $f$ is the correction factor of joint orientation at a coal seam. The correction factor $\mathrm{f}$ is equal to (1-B) where $\mathrm{B}$ is the orientation factor for a critical joint set, $\sigma_{c . w}$ is the strength of first $0.75 \mathrm{~m}$ of the coal face in depth and $\sigma_{y y}$ is the vertical induced stress on the $0.75 \mathrm{~m}$ distance of the coal face.

$$
S F=\frac{\frac{\sigma_{c . w}}{\sigma_{y y}}}{f}
$$

The interaction matrix was created based on the nine effective parameters and its results are shown in Table 2. The coding of a matrix was carried out based on experiences and views of experts in the field of longwall min-

Table 2: Generation of interaction matrix

\begin{tabular}{|c|c|c|c|c|c|c|c|c|}
\hline $\mathrm{P}_{1}$ & 2 & 1 & 0 & 0 & 3 & 0 & 2 & 0 \\
\hline 1 & $\mathrm{P}_{2}$ & 1 & 0 & 0 & 0 & 0 & 0 & 0 \\
\hline 0 & 1 & $\mathrm{P}_{3}$ & 0 & 0 & 1 & 0 & 1 & 0 \\
\hline 2 & 0 & 1 & $\mathrm{P}_{4}$ & 0 & 2 & 1 & 1 & 0 \\
\hline 0 & 0 & 1 & 0 & $\mathrm{P}_{5}$ & 1 & 0 & 1 & 0 \\
\hline 0 & 0 & 1 & 0 & 0 & $\mathrm{P}_{6}$ & 0 & 1 & 0 \\
\hline 0 & 0 & 1 & 0 & 1 & 3 & $\mathrm{P}_{7}$ & 1 & 0 \\
\hline 0 & 0 & 0 & 0 & 1 & 2 & 0 & $\mathrm{P}_{8}$ & 0 \\
\hline 3 & 0 & 2 & 1 & 1 & 1 & 0 & 1 & $\mathrm{P}_{9}$ \\
\hline
\end{tabular}

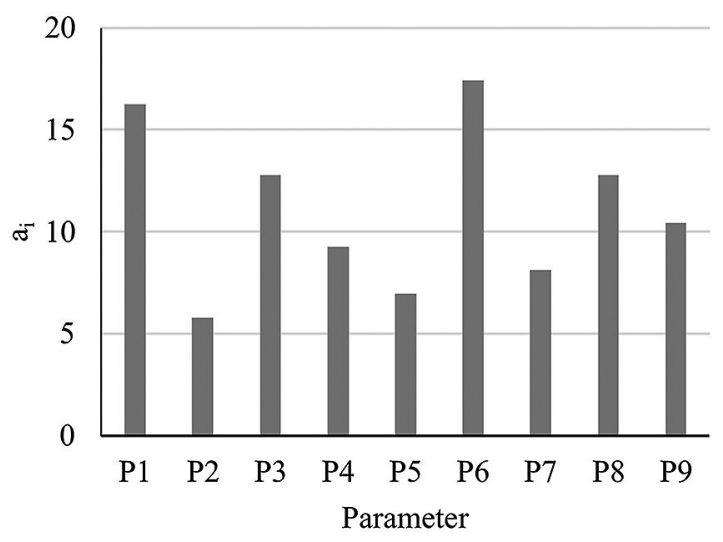

Figure 4: Determined $a_{i}$ values of the parameters

ing. Also, Figure 4 indicates the $a_{1}$ values determined by Equation 1 for each parameter. According to these results, $\mathrm{P}_{6}, \mathrm{P}_{1}, \mathrm{P}_{3}$ and $\mathrm{P}_{8}$ appeared to have more interaction in the system.

Rating of the parameters is essential to calculate the $\mathrm{Q}_{\mathrm{i}} / \mathrm{Q}_{\max }$ in Equation 2. So, the rating was carried out based on their influence on the roof falls (see Table 3). In this rating, 0 indicates the worst condition (maximum probability of the occurrence of a roof fall) and a higher number, for example 4 in the rating of $\mathrm{P}_{1}$, the best condi- 
Table 3: Rating of the parameters

\begin{tabular}{|c|c|c|c|c|c|c|c|}
\hline \multirow{2}{*}{$\begin{array}{l}\begin{array}{l}\text { Code of } \\
\text { parameter }\end{array} \\
\text { P1 }\end{array}$} & \multicolumn{7}{|c|}{ Value/description and rating } \\
\hline & Value & $<21$ & $21-40$ & $41-60$ & $61-80$ & $81-100$ & \\
\hline & Rating & 0 & 1 & 2 & 3 & 4 & \\
\hline \multirow[t]{2}{*}{$\mathrm{P}_{2}$} & Value & Week & Moderate & Strong & & & \\
\hline & Rating & 0 & 1 & 2 & & & \\
\hline \multirow{2}{*}{$\mathrm{P}_{3}$} & Value & $<0.75$ & $0.75-1$ & $1-1.25$ & $1.25<$ & & \\
\hline & Rating & 0 & 1 & 2 & 3 & & \\
\hline \multirow[t]{2}{*}{$\mathrm{P}_{4}$} & Value & $<0.25$ & $0.25-0.5$ & $0.5-0.75$ & $0.75-1$ & $1-1.25$ & $1.25<$ \\
\hline & Rating & 0 & 1 & 2 & 3 & 4 & 5 \\
\hline \multirow[t]{2}{*}{$\mathrm{P}^{5}$} & Value & $<15$ & $15-30$ & $30-45$ & $45<$ & & \\
\hline & Rating & 3 & 2 & 1 & 0 & & \\
\hline \multirow[t]{2}{*}{$\mathrm{P}_{6}$} & Value & $<100$ & $100-150$ & $150-200$ & $200-300$ & $300<$ & \\
\hline & Rating & 3 & 4 & 2 & 1 & 0 & \\
\hline \multirow[t]{2}{*}{$\mathrm{P}_{7}$} & Value & $<21$ & $21-40$ & $41-60$ & $61-80$ & $81-100$ & \\
\hline & Rating & 0 & 1 & 2 & 3 & 4 & \\
\hline \multirow[t]{2}{*}{$\mathrm{P}_{8}$} & Value & $\begin{array}{l}\text { Manual } \\
\text { Control } \\
\end{array}$ & $\begin{array}{l}\text { Automatic } \\
\text { Control }\end{array}$ & $\begin{array}{l}\text { Electrohydraulic } \\
\text { Control }\end{array}$ & & & \\
\hline & Rating & 2 & 4 & 5 & & & \\
\hline \multirow[t]{2}{*}{$\mathrm{P}_{9}$} & Value & No Present & $h_{\text {im.max }}>$ & $\mathrm{h}_{\mathrm{im} \cdot \max } \leq \& \leq 20 \mathrm{~m}$ & $20 \mathrm{~m}<$ & & \\
\hline & Rating & 1 & 0 & 4 & 3 & & \\
\hline
\end{tabular}

tion (minimum probability of the occurrence of a roof fall). For $\mathrm{P}_{9}, \mathrm{~h}_{\text {im.max }}$ is the maximum caving height of immediate roof which can be determined by Equation 5 (Peng, 2006). In Equation 5, $\mathrm{H}_{\mathrm{f}}$ is the mining height at the longwall face and $\mathrm{K}$ is the volumetric expansion coefficient of caved rock.

$$
h_{\text {im.max }}=\frac{H_{f}}{K-1}
$$

Determining the intervals for rating $\mathrm{P}_{1}$ and $\mathrm{P}_{7}$ were carried out based on five classes of rock mass quality including "very poor rock", "poor rock", "fair rock", "good rock" and "very good rock". According to the lack of quantitative data, a qualitative rating was considered for $\mathrm{P}_{2}$ and $\mathrm{Q}_{\mathrm{i}}$ was determined based on the lithology of strata. $\mathrm{P}_{3}$ was rated in four classes based of the safety factor of the face. Bound of last class was determined based on the minimum recommended SF for design in rock. A rating of $\mathrm{P}_{4}$ was considered in six classes based on the number of joints into the exposed span created by a cutting machine and the best condition is when two joints are not simultaneously located in the exposed span at the front of the roof. A rating for $\mathrm{P}_{5}$ was carried out in four classes. Faces with an inclination of less than 15 degrees and more than 45 degrees have the best and worst operation conditions, respectively. Increasing the inclination increases the required support load, decreases the face advance rate and creates other problems in longwall panels. Coal seams with an inclination of more than 45 degrees can rarely be mechanized due to the worst operation conditions. A rating of $\mathrm{P}_{6}$ was considered based on Aghababaei et al. (2015). A qualitative rating was adopted for $\mathrm{P}_{8}$. Using the automatic control

Table 4: Categorizing roof falls at the longwall face based on the required support operation and their hazards at the Parvadeh-I coal mine

\begin{tabular}{|l|l|l|}
\hline Type of roof fall & Height of roof fall $(\mathbf{H})$ & Description \\
\hline Local & $\mathrm{H}<0.3$ & $\begin{array}{l}\text { The roof support operation is not required for this type of roof fall. Dilution is } \\
\text { the most important hazards of this type. }\end{array}$ \\
\hline Small & $0.3 \leq \mathrm{H} \leq 1.5$ & $\begin{array}{l}\text { For this type of roof fall, a support operation rarely causes delay in face } \\
\text { advancing. Roof support by forepoling and crib are usual for this roof fall } \\
\text { type at Parvadeh-I coal mine. }\end{array}$ \\
\hline Moderate & $1.5<\mathrm{H} \leq 5$ & $\begin{array}{l}\text { Roof support by forepoling and crib, and in a few cases, using the four-ply } \\
\text { and filling by chaff or geofoam are applied for this roof fall at the Parvadeh-I } \\
\text { coal mine. }\end{array}$ \\
\hline High & $\mathrm{H}>5$ & $\begin{array}{l}\text { This type with any length may cause the serious problems. Roof support by } \\
\text { four-ply and filling by chaff or geofoam are applied for this roof fall type at } \\
\text { the Parvadeh-I coal mine. }\end{array}$ \\
\hline
\end{tabular}


Table 5: Statistics of recorded roof falls in the considered panels

\begin{tabular}{|l|l|l|l|l|l|l|l|}
\hline Type of roof fall & $\begin{array}{l}\text { Recorded } \\
\text { Number }\end{array}$ & $\begin{array}{l}\text { Mean } \\
\text { of length }(\mathbf{m})\end{array}$ & $\begin{array}{l}\text { Range } \\
\text { of length }\end{array}$ & $\begin{array}{l}\text { Mean } \\
\text { of height (m) }\end{array}$ & $\begin{array}{l}\text { Range } \\
\text { of height }\end{array}$ & $\begin{array}{l}\text { Mean } \\
\text { of width (m) }\end{array}$ & $\begin{array}{l}\text { Range } \\
\text { of width }\end{array}$ \\
\hline Small & 172 & 15 & $1.5-183$ & 0.7 & $0.3-1.5$ & 0.7 & $0.5-3$ \\
\hline Moderate & 135 & 10.9 & $1.5-43.5$ & 3 & $1.6-5$ & 1.5 & $0.5-5.7$ \\
\hline High & 14 & 9 & $3-19.5$ & 8.7 & $6-20$ & 2 & $0.5-4$ \\
\hline
\end{tabular}

system improves the operation significantly compared to the manual control which is not the same case with a change from an automatic control to an electrohydraulic system. The division for $\mathrm{P}_{8}$ was based on this point that locating a strong cantilever layer into $h_{\text {im.max }}$ creates the highest pressure on powered supports.

\section{Definition of damaged regions and categorizing the types of roof fall}

Damaged regions are parts of the panels with a high probability of roof falls. In these regions, the size of a roof fall is considerable and needs to be supported. If the size of a roof fall is very high, it can cause very serious problems. Height is the most important dimension of a roof fall. The severity of instability and the degree of the required support operation is a function of the falling height. Therefore, a categorization was presented based on the height of a recorded roof fall in the Parvadeh-I coal mine (see Table 4). Due to the low importance and the lack of the need to support the local roof falls, no fall with a height of less than $0.3 \mathrm{~m}$ was recorded in the longwall faces of this mine. A statistical description of the data regarding recorded roof falls is shown in Table $\mathbf{5}$.

\section{Results and discussion}

The presented model was examined on the considered case study and its results are discussed in this section. A description of the determined VIs on the case study is outlined in Table 6 . The R-squared value $\left(\mathrm{R}^{2}\right)$ between the SRF and estimated average of VIs is presented in Figure 5 for all estimated VIs. To determine the influence of unrecorded small roof falls with a height of 0.3 to $0.9 \mathrm{~m}$ in $\mathrm{E}_{0}, \mathrm{E}_{3}, \mathrm{~W}_{0}, \mathrm{~W}_{1}$ and $\mathrm{W}_{2}$, an equivalent volume

Table 6: Statistical description of determined VIs (omit outlier data from $\mathrm{E}_{3}$ )

\begin{tabular}{|l|l|l|l|l|l|}
\hline $\begin{array}{l}\text { Code of } \\
\text { panel }\end{array}$ & $\begin{array}{l}\text { Ave. } \\
\text { VI }\end{array}$ & $\begin{array}{l}\text { Min } \\
\text { VI }\end{array}$ & $\begin{array}{l}\text { Max } \\
\text { VI }\end{array}$ & $\begin{array}{l}\text { St. Dev. } \\
\text { of VIs }\end{array}$ & $\begin{array}{l}\text { Outlier data } \\
\text { (based on } \pm \text { 2SD) } \\
\%\end{array}$ \\
\hline $\mathrm{E}_{0}$ & 46.3 & 44.1 & 55.8 & 3.3 & 3.8 \\
\hline $\mathrm{E}_{2}$ & 71.1 & 61.7 & 83.5 & 6.2 & 0 \\
\hline $\mathrm{E}_{3}$ & 61.4 & 56.3 & 66.6 & 2.2 & 0 \\
\hline $\mathrm{W}_{0}$ & 53.6 & 50.0 & 63.4 & 4.9 & 0 \\
\hline $\mathrm{W}_{1}$ & 49.4 & 44.9 & 62.7 & 5.0 & 6.25 \\
\hline $\mathrm{W}_{2}$ & 52.4 & 52.2 & 54.6 & 0.6 & 6.0 \\
\hline
\end{tabular}

of small roof falls (with a height of 0.3 to $0.9 \mathrm{~m}$ ) was calculated for these panels and added to the recorded volume of roof falls of each panel and then a new SRF was determined. The new results are presented in Figure 6. This calculation was carried out by an average of height, length and width of small recorded roof falls in the height range of 0.3 to $0.9 \mathrm{~m}$ in the $\mathrm{E}_{2}$ panel, and also the ratio of small roof fall number to sum number of the moderate and high roof falls in the considered panel.

In this research, the relationships of the panel width, face inclination, ratio of joint spacing to cutting depth, safety factor of face, CMRR and floor RMR (quantitative parameters) with the SRF were investigated and results are presented in Figure 7, respectively. A statistical analysis of the average amounts of parameters for the considered case study is illustrated in Table 7. In this regard, a sensitivity analysis was applied to determine the effect of each of these parameters on SRF (see Table 8).

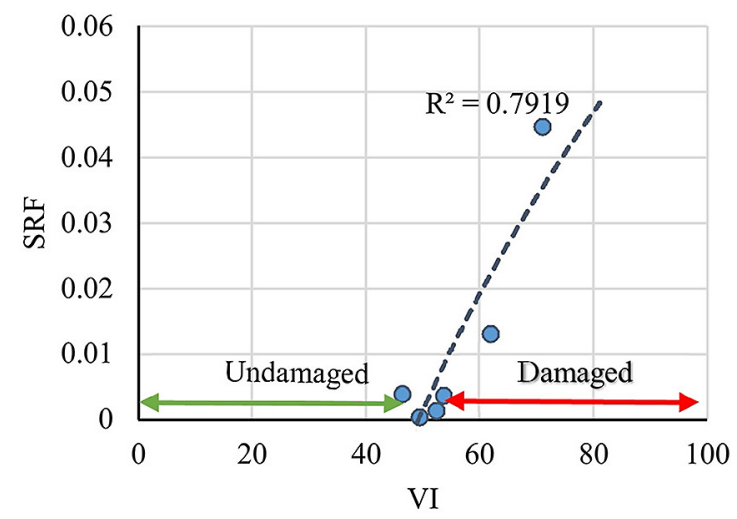

Figure 5: Correlation between VIs and SRF, a logarithmic regression analysis

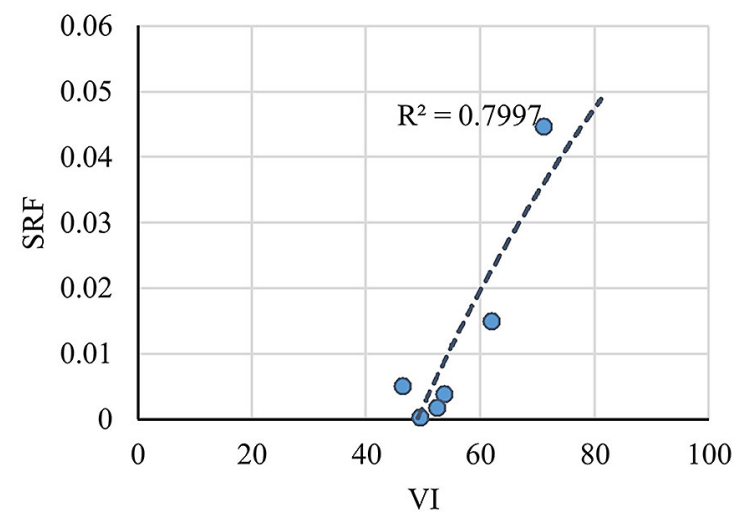

Figure 6: Correlation between VIs and SRF, add equivalent not recorded small roof fall, a logarithmic regression analysis 
Table 7: Statistical description of parameters for considered case study (omit outlier data from detail data of $\mathrm{P}_{4}$ )

\begin{tabular}{|l|l|l|l|l|l|}
\hline Parameter & Mean & Min & Max & St. Dev. & $\begin{array}{l}\text { Outlier data } \\
\text { (based on } \pm \text { 2SD) \% }\end{array}$ \\
\hline Panel width (m) & 203.5 & 190.5 & 213 & 7.97 & 0 \\
\hline CMRR & 43.2 & 33.07 & 50.38 & 7.55 & 0 \\
\hline Ratio of Joint spacing to cutting depth & 1.22 & 0.38 & 1.88 & 0.489 & 0 \\
\hline Safety factor of face & 1.42 & 0.74 & 3.08 & 0.89 & 0 \\
\hline Face inclination (degree) & 16.3 & 12.4 & 24.9 & 4.9 & 0 \\
\hline Floor RMR & 36.2 & 31.2 & 42 & 3.9 & 0 \\
\hline
\end{tabular}
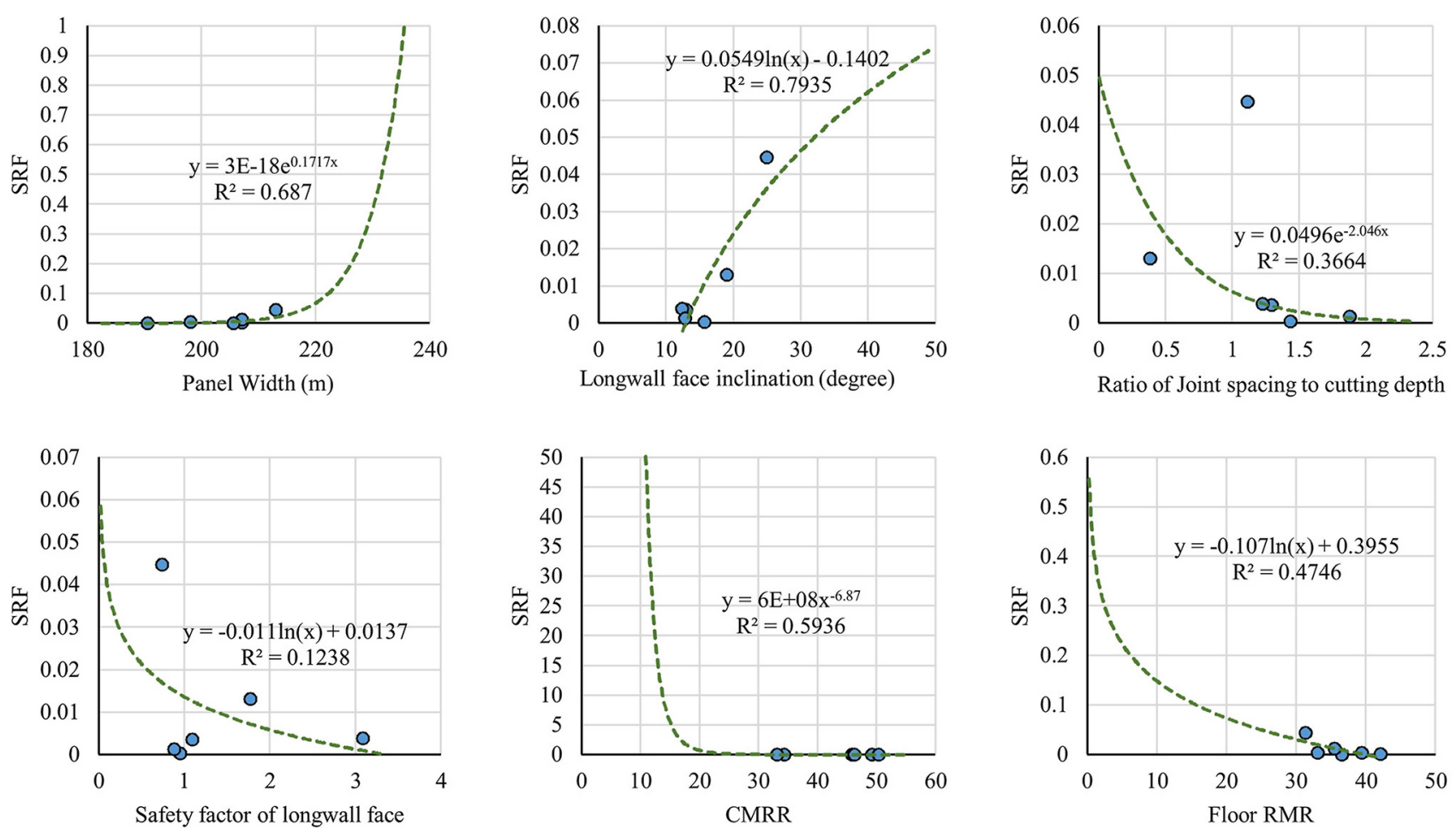

Figure 7: Correlation between parameters $\mathrm{P}_{6}, \mathrm{P}_{5}, \mathrm{P}_{4}, \mathrm{P}_{3}, \mathrm{P}_{1}$ and $\mathrm{P}_{7}$ with SRF (an exponential, logarithmic, regression, exponential, logarithmic, power and logarithmic analyses, respectively)

Table 8: Variations percentage of SRF with increase of each parameter, variation percentage investigated in the direction of increase the SRF

\begin{tabular}{|l|l|l|l|l|l|l|}
\hline Parameter & $\begin{array}{l}\text { SRF variation } \\
\text { percentage } \\
\text { with } \mathbf{1 0 \%} \\
\text { variation }\end{array}$ & $\begin{array}{l}\text { SRF variation } \\
\text { percentage } \\
\text { with 20\% } \\
\text { variation }\end{array}$ & $\begin{array}{l}\text { SRF variation } \\
\text { percentage } \\
\text { with 30\% } \\
\text { variation }\end{array}$ & $\begin{array}{l}\text { SRF variation } \\
\text { percentage } \\
\text { with 50\% } \\
\text { variation }\end{array}$ & $\begin{array}{l}\text { SRF variation } \\
\text { percentage } \\
\text { with 70\% } \\
\text { variation }\end{array}$ & $\begin{array}{l}\text { SRF variation } \\
\text { percentage } \\
\text { with 90\% } \\
\text { variation }\end{array}$ \\
\hline Panel Width & 2,511 & 68,071 & $1.77 \times 10^{6}$ & $1.21 \times 10^{9}$ & $8.27 \times 10^{11}$ & $5.63 \times 10^{14}$ \\
\hline CMRR & 106 & 363 & 1,059 & 11,597 & 390,900 & $7.41 \times 10^{8}$ \\
\hline Floor RMR & 1,427 & 3,023 & 4,832 & 9,389 & 16,309 & 31,191 \\
\hline $\begin{array}{l}\text { Ratio of Joint spacing to } \\
\text { cutting depth }\end{array}$ & 85 & 241 & 531 & 2,052 & 7,245 & 24,969 \\
\hline Safety factor of face & 72 & 152 & 243 & 472 & 820 & 1,568 \\
\hline Face inclination & 22 & 41 & 59 & 92 & 120 & 145 \\
\hline
\end{tabular}

To analyse the recorded roof falls and perform an accurate determination of the boundary between the undamaged and damaged regions, statistical analysis was performed. Frequency distribution of the recorded roof falls based on corresponding calculated VIs are shown in Figure 8 for small and moderate falls, high falls and all of the corresponding roof falls. To construe the relationship between the recorded roof falls and the calcu- 

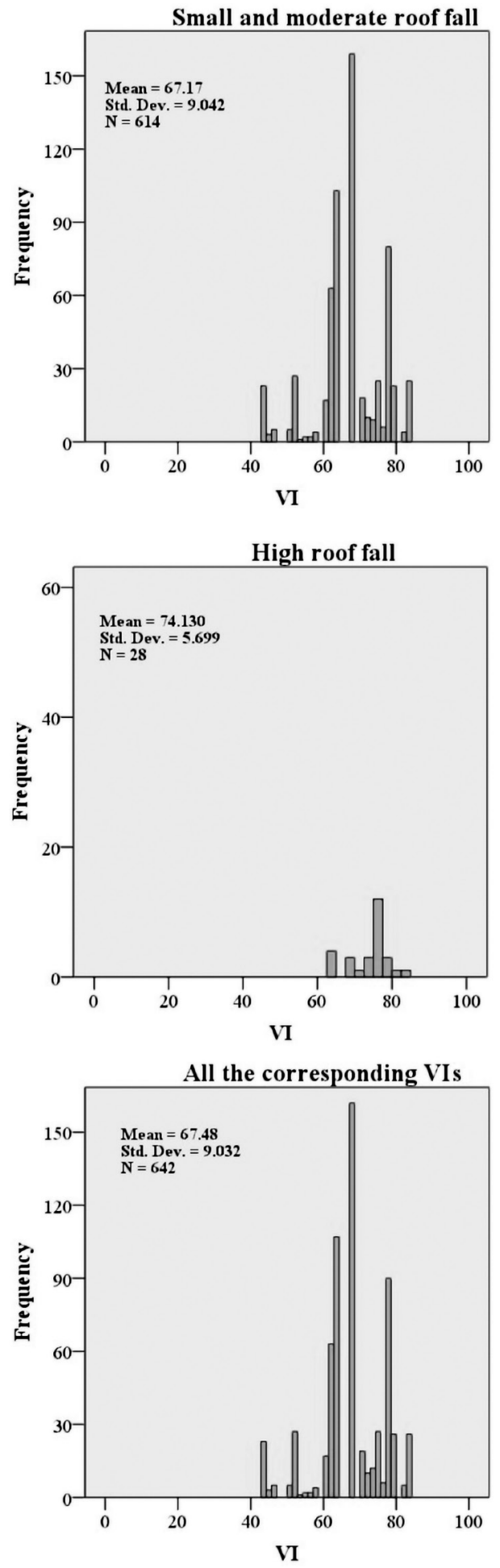

Figure 8: VI-Frequency distribution graph about recorded roof falls lated VIs, statistical results are illustrated in Table 9. According to the results (see Figure 8 and Table 9), classification of the damaged and undamaged regions was performed (see Table 10). In the following image, the regions were mapped in the considered panels based on the presented classification and results of the model (see Figure 9).

The boundary between the undamaged and damaged regions is shown in Figure 5 where the regression line intersects with the horizontal axis. VI at this boundary is equal to 49 where the SRF is equal to 0 . The accurate value of VI at boundary of undamaged-damaged regions was determined to be equal to 46 according to the obtained results from the statistical investigation of recorded roof falls (see Table 9).

In usual conditions, the intensity and volume of roof falls increases under the worst geotechnical conditions; which is noticeably demonstrated according to the results. The extension of continuous very high risk values in a large critical region may cause limiting of the panel in this region before mining or stopping the operation and relocation of the longwall face during mining.

Accurate determination of effective parameters on the system/hazard has a very important role in achieving the actual results. Comparing the parameter value with values of relevant hazards or options can be one of the criteria to perform this judgement so that the obtained results indicate there is a relationship for the proposed model.

The results demonstrated that one of the best ways to identify the damaged and undamaged regions is through the determination of the values of relevant hazards (roof falls) in the regions and investigating their relationship with the corresponding risks (VIs). This process could result in the determination of the boundary between the undamaged and damaged regions. However, accuracy of the results depends on the model validation. So, valuation of the model is very determinant.

There are criteria that could be considered to validate the model. One of the most important criteria is investigating the relationship outputs of the model and the values of relevant hazards. Studying the relationship between the values of selected effective parameters and the values of relevant hazards could be another auxiliary criterion for this purpose. It could be called the verification of selected parameters. The results proved that the presented model is at an acceptable level.

Table 9: Statistical results on type of roof fall

\begin{tabular}{|l|l|l|l|l|l|}
\hline Type of roof fall & Min. $\boldsymbol{V I}$ & Max. $\boldsymbol{V I}$ & $\begin{array}{l}\boldsymbol{V I} \text { at 5\% } \\
\text { cumulative percent }\end{array}$ & $\begin{array}{l}\boldsymbol{V I} \text { at 10\% } \\
\text { cumulative percent }\end{array}$ & Skewness \\
\hline Small and Moderate & 44 & 84 & 46 & 52 & -0.55 \\
\hline High & 63 & 84 & 63 & 63 & -0.71 \\
\hline Whole of roof falls & 44 & 84 & 50 & 54 & -0.58 \\
\hline
\end{tabular}


Table 10: Categorizing the damaged and undamaged regions on a roof fall at longwall panels

\begin{tabular}{|l|l|l|}
\hline $\begin{array}{l}\text { Region } \\
\text { code }\end{array}$ & $\begin{array}{l}\text { Range } \\
\text { of } \boldsymbol{V I}\end{array}$ & Description \\
\hline Safe & 0 to 46 & $\begin{array}{l}\text { In these regions no significant roof } \\
\text { fall has occurred. The majority of } \\
\text { roof falls are in local and rarely } \\
\text { small scales. }\end{array}$ \\
\hline Moderate & 46 to 52 & $\begin{array}{l}\text { The majority of roof falls are in } \\
\text { small and rarely moderate scales. } \\
\text { Negligence in these regions can } \\
\text { provide a worse condition. }\end{array}$ \\
\hline Danger & 52 to 63 & $\begin{array}{l}\text { In these regions, the size of falls is } \\
\text { considerable. Roof falls increase } \\
\text { operation costs and decrease } \\
\text { productivity. Timely support } \\
\text { operation decreases the volume of } \\
\text { fallings. Negligence in these regions } \\
\text { can lead to a critical condition. }\end{array}$ \\
\hline Critical & 63 to 100 & $\begin{array}{l}\text { Large dimension of a roof fall that } \\
\text { may cause very serious problems. }\end{array}$ \\
\hline
\end{tabular}

\section{Conclusion}

The obtained results from testing the RES-based model on the considered case study showed that there is an acceptable correlation between the value of the determined risk and special roof fall (SRF). These results indicated that the presented RES-based model could be used to identify the damaged regions and predict the damaging regions prior to the mining operation.

Statistical investigations of recorded roof falls showed that along with an increase in the estimated VIs, the number and volume of the roof falls increased, which is quite consistent with reality. By investigating and comparing the evaluated values of VI in the considered panels and their corresponding recorded roof falls, the damaged regions are distinguished from the undamaged regions. Based on these investigations, four classes including safe, moderate, danger and critical regions were used to classify and identify the safe and damaged regions prior to mining operations. An accurate value of
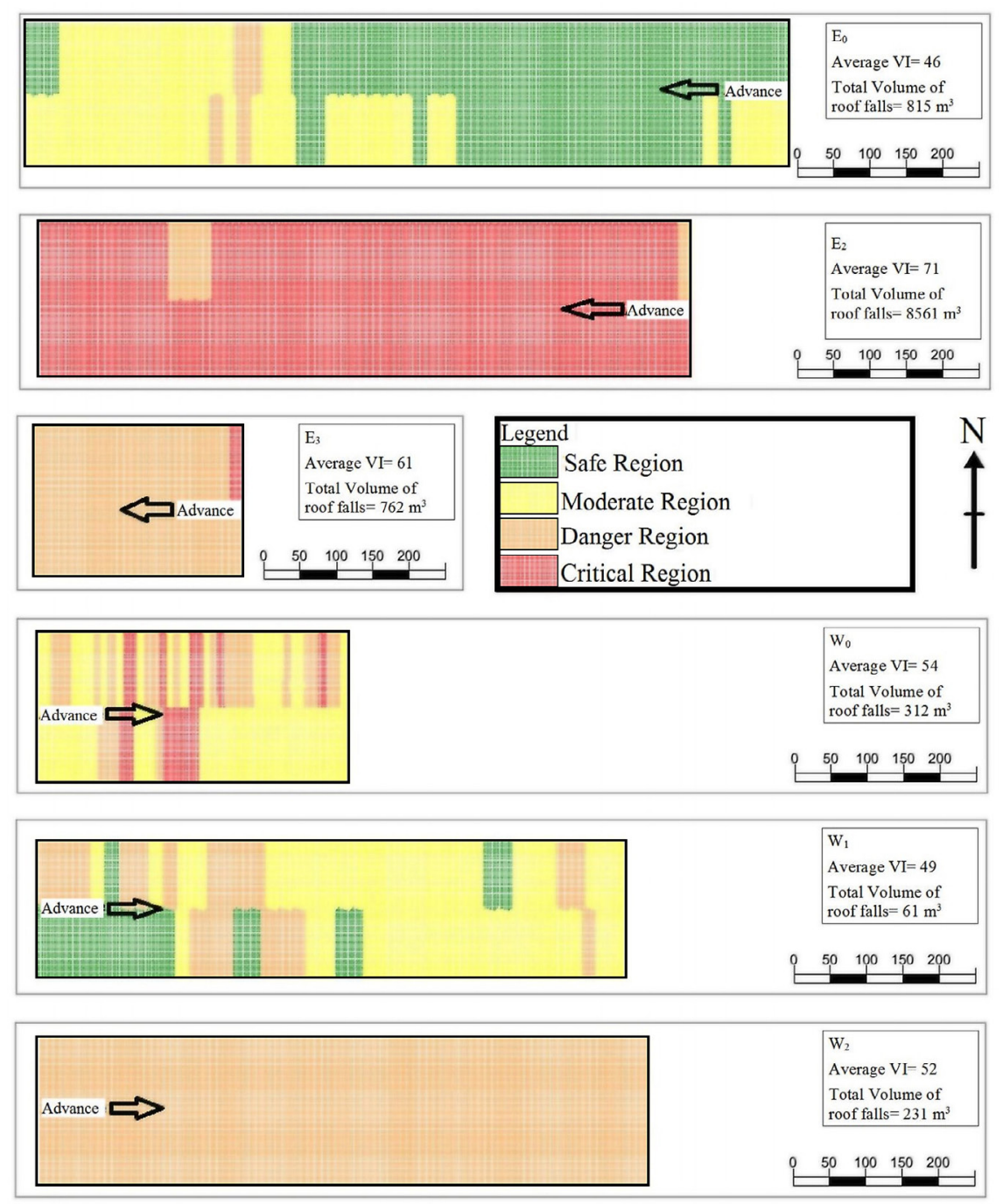

Figure 9: Identifying the undamaged and damaged regions by the RES-based model and the recorded roof falls 
$\mathrm{VI}$ at the boundary of undamaged-damaged regions was determined to be equal to 46 .

The presented methodology provides a reliable tool to determine the damaged regions before operations that could be used for all parts of underground coal mines. This methodology could provide a fantastic tool to avoid the application of special arrangements and additional costs in unnecessary regions and reduce the damage and injury rate due to the failure to consider special measures in critical regions.

\section{Acknowledgment}

Here, it is worthy to appreciate the services of the engineering team of Parvadeh-I coal mine in particular Ali Hosseini, headman of education and Ali Keshvari, the mine manager.

\section{References}

Adoko, A.C., Phumaphi, P.T. and Zvarivadza, T. (2016): Quantifying Rock Mass Behavior around Underground. American Rock Mechanics Association.

Aghababaei, S., Saeedi, G. and Jalalifar, H. (2015): Risk analysis and prediction of floor failure mechanisms at longwall face in parvadeh-I coal mine using rock engineering system (RES). Rock Mechanics and Rock Engineering. DOI 10.1007/s00603-015-0884-x.

Aghababaei, S., Jalalifar, H. and Saeedi, G. (2019): Prediction of face advance rate and determination of the operation efficiency in retreat longwall mining panel using rock engineering system. International Journal of Coal Science and Technology. DOI 10.1007/s40789-019-0245-6.

Andrieux, P. and Hadjigeorgiou, J. (2008): The destressability index methodology for the assessment of the likelihood of success of a large-scale confined destress blast in an underground mine pillar. International Journal of Rock Mechanics and Mining Sciences. 45, 407-421.

Bahri Najafi, A., Saeedi, G. and Ebrahimi Farsangi, MA. (2014): Risk analysis and prediction of out-of-seam dilution in longwall mining. International Journal Rock Mechanics and Mining Sciences. 70, 115-122.

Benardos, A.G. and Kaliampakos, D.C. (2004): A methodology for assessing geotechnical hazards for TBM tunneling-illustrated by the Athens Metro, Greece. International Journal of Rock Mechanics and Mining Sciences. 41, 987-999.

Canbulat, I., Zhang, C., Black K., Johnston, J. and McDonald, S. (2017): Assessment of Sinkhole Risk in Shallow Coal Mining. Proceedings of the 10th Triennial Conference on Mine Subsidence. pp 331-337.

Deb, D. (2003): Analysis of coal mine roof fall rate using fuzzy reasoning techniques. International Journal of Rock Mechanics and Mining Sciences. 40, 251-7.

Duzgun, H.S.B. and Einstein, H.H. (2004): Assessment and management of roof fall risks in underground coal mines. Safety Science. 42, 23-41.
Ghanbari, K., Atae, M., Sereshki, F. and Saffari, A. (2018): Determination and assessment of coal bed methane potential using rock engineering systems. Journal of Mining and Environment. Vol. 9, No. 3, 605-621. DOI: 10.22044/jme. 2018.6649.1486.

Ghasemi, E., Ataei, M., Shahriar, K., Sereshki F., Jalali, S.E. and ramenzanzadeh, A. (2012): Assessment of roof fall risk during retreat mining in room and pillar coal mines. International Journal of Rock Mechanics and Mining Sciences. 54, 80-9.

Hudson, J.A. (1992): Rock engineering systems: theory and practice. Ellis Harwood Ltd.

IRASCO., IRITEC and Cementation SKANSKA. (2005a): Basic Design Report. Appendix A, Rating of rock exposures \& Appendix G, Geotechnical Data. Parvadeh, Tabas Coal Mine Project, Iran.

IRASCO., IRITEC, and Cementation SKANSKA. (2005b): Basic Design Report. Vol. 2 to 5. Parvadeh, Tabas Coal Mine Project, Iran.

Li, N., Z. Naghadehi, M. and Jimenez, R. (2019): Evaluating shortterm rock burst damage in underground mines using a systems approach. International Journal of Mining, Reclamation and Environment. DOI: 10.1080/17480930. 2019.1657654

Luo, X., Wang, Z., Fu, J., Bai, J., Wang, J. and Chen, Y. (2019): A method for evaluating the risk of ground collapse in goaf based on unascertained measure. Institute of Electrical and Electronics Engineers, International Conference on Signal Processing, Communications and Computing. 978-1-7281 -1708-9. DOI: 10.1109/ICSPCC46631.2019.8960713.

Maiti, J. and Khanzode, V.V. (2009): Development of a relative risk model for roof and side fall fatal accidents in underground coal mines in India. Safety Science. 47, 1068-76.

Molinda, G.M., Mark, C. and Dolinar, D. (2000): Assessing coal mine roof stability through roof fall analysis. In: Proceedings of the new technology for coal mine roof support. US Department of Health and Human Services, Centers for Disease Control and Prevention. National Institute for Occupational Safety and Health, NIOSH Publication. 9453, 53-72.

Najafi, M. and Rafiee, R. (2019): Development of a new index for methane drainageability of a coal seam using the fuzzy rock engineering system. The Mining-Geology-Petroleum Engineering Bulletin. DOI: 10.17794/rgn.2019.4.4.

Palei, S.K. and Das, S.K. (2009): Logistic regression model for prediction of roof fall risks in board and pillar workings in coal mines: an approach. Safety Science. 47, 88-96.

Peng, S.S. (2006): Longwall mining. 2nd edition. Morgantown, West Virginia University.

Prusek, S., Rajwa, S., Wrana, A. and Krzemień, A. (2017): Assessment of roof fall risk in longwall coal mines. International Journal of Mining, Reclamation and Environment. 31, 558-574.

Rafiee, R., Ataei, M., KhaloKakaie, R., Jalali, S. M. E. and Sereshki, F. (2015): A fuzzy rock engineering system to assess rock mass cavability in block caving mines. Neural Computing and Applications. DOI 10.1007/s00521-0152007-8. 
Rafiee, R., Mohammadi, S., Ataei, M. and Khalookakaie, E. (2018): Application of fuzzy RES and fuzzy DEMATEL in the rock behavioral systems under uncertainty. Geosystem Engineering. DOI: 10.1080/12269328.2018.1452051.

Razania, M., Yazdani-Chamzini, A. and Haji Yakhchali, S. (2013): A novel fuzzy inference system for predicting roof fall rate in underground coal mines. Safety science. $55,26-33$.

Saffari, A., Sereshki, F., Ataei, M. and Ghanbari, K. (2013): Applying Rock Engineering Systems (RES) approach to Evaluate and Classify the Coal Spontaneous Combustion Potential in Eastern Alborz Coal Mines. International Journal of Mining and Geotechnical Engineering. Vol.47, No.2, pp. 115-127.

Sun, Y., Jin, F., Ji, M., Wang, H. and Li, Y. (2019): A Model Base Framework for the Risk Assessment and Prevention of Geological Disasters in Coal Mines. Geo-informatics in Sustainable Ecosystem and Society. CCIS 980, pp. 394411, https://doi.org/10.1007/978-981-13-7025-0_40.
Vaziri, V., K. Hamidi, J. and Sayadi, A.R. (2017): An integrated GIS based approach for geohazards risk assessment in coal mines. Environmental Earth Sciences. 77:29. https:// doi.org/10.1007/s12665-017-7198-0.

Zhang, P., Van Dyke, M., Su, D., Esterhuizen, E. and Trackemas, J. (2018): Roof Failure in Longwall Headgates, Causes, Risks, and Prevention. American Rock Mechanics Association. Document ID: ARMA-2018-956.

Zhou, Q., Herrera, J. and Hidalgo, A. (2017): Development of a quantitative assessment approach for the coal and gas outbursts in coal mines using rock engineering systems. International Journal of Mining, Reclamation and Environment. DOI: 10.1080/17480930.2017.1326077.

Zhou, Z., Zang, H., Cao, W., Du, X., Chen, L. and Ke, C. (2019): Risk assessment for the cascading failure of underground pillar sections considering interaction between pillars. International Journal of Rock Mechanics and Mining Sciences. 124 (2019) 104142. https://doi.org/10.1016/j. ijrmms.2019.104142.

\section{SAŽETAK}

\section{Analiza rizika od pada krovine i predviđanje oštećenja područja pri rudarenju ugljena povlačenjem širokoga čela}

U ovome radu prikazan je model utemeljen na sustavima inženjerskih stijena za procjenu rizika od urušavanja (pada) krovine i određivanje oštećenih područja primjenom zabilježenih padova krovine, prije rudarenja metodom širokoga čela. Razmatrana je studija slučaja koja je ispitala model. Rezultati su pokazali da je razina utvrđenoga rizika imala relativno prihvatljivu korelaciju i kompatibilnost s posebnim padom krovine (PPK), s koeficijentom determinacije $\left(\mathrm{R}^{2}\right)$ jednakim 0,792 za sve procijenjene indekse ranjivosti (IR) u razmatranim područjima rudarenja. Istražujući i uspoređujući procijenjene vrijednosti indeksa ranjivosti na razmatranim područjima i pripadajućim zabilježenim padovima krovine, otkrivena su oštećena područja unutar onih neoštećenih. Na temelju tih istraživanja izvedene su četiri klase: sigurno, umjereno, opasno i kritično područje, radi identificiranja sigurnih, umjereno opasnih i kritičnih područja prije rudarskih operacija. Rezultati istraživanja pokazali su da je identificiranje štetnih područja razvijenim pristupom prikladno za izradu detaljnoga operativnoga plana za kontrolu pada krovine na širokom čelu. Konačno, model temeljen na inženjerskim sustavima stijena može se koristiti i drugdje za iste uvjete, a predstavljena metodologija može se primijeniti i na ostale dijelove podzemnih rudnika ugljena.

\section{Ključne riječi:}

urušavanje krovine, stijenski sustavi, oštećenja područja, rudarenje metodom širokoga čela, rudnik ugljena Parvadeh-I

\section{Authors' contribution}

Sajjad Aghababaei (MSc Student, researcher): participated in running models and formulation of simulation and optimization process, initialized the idea. Gholamreza Saeedi (Associated Professor): participated in the development of research methodology, verification and evaluation of the models, data analysis and completed literature review. Hossein Jalalifar (Full Professor): executed the optimization process, regulated the research process and reviewed the final work. 